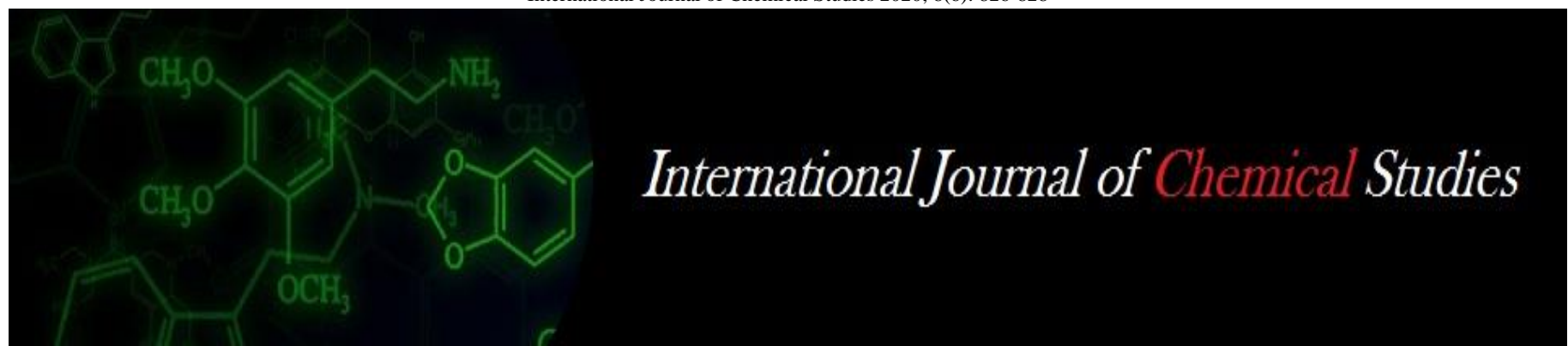

P-ISSN: 2349-8528

E-ISSN: 2321-4902

www.chemijournal.com

IJCS 2020; 8(6): 826-828

(C) 2020 IJCS

Received: 12-08-2020

Accepted: 09-10-2020

\section{Basavaraj BR}

Department of Agronomy,

College of Agriculture,

University of Agricultural and

Horticultural Sciences,

Shivamogga, Karnataka, India

Sunil C

Department of Agronomy,

College of Agriculture,

University of Agricultural and

Horticultural Sciences,

Shivamogga, Karnataka, India

\section{Mavarkar NS}

Department of Agronomy,

College of Agriculture,

University of Agricultural and

Horticultural Sciences,

Shivamogga, Karnataka, India

\section{Mallikarjuna HB}

Department of Agronomy,

College of Agriculture,

University of Agricultural and

Horticultural Sciences,

Shivamogga, Karnataka, India

\section{Ganapathi}

Department of Agronomy,

College of Agriculture,

University of Agricultural and

Horticultural Sciences,

Shivamogga, Karnataka, India

Corresponding Author:

Basavaraj BR

Department of Agronomy,

College of Agriculture,

University of Agricultural and

Horticultural Sciences,

Shivamogga, Karnataka, India

\section{Effect of sowing date and soybean varieties on nutrient uptake studies in southern transition zone of Karnataka}

\author{
Basavaraj BR, Sunil C, Mavarkar NS, Mallikarjuna HB and Ganapathi
}

DOI: https://doi.org/10.22271/chemi.2020.v8.i61.10872

\section{Abstract}

Field experiments was carried out in Zonal Agricultural and Horticultural Research Station, Bavikere, Chikkamagalore, Karnataka during 2019-20. Identify the most suitable variety, suitable sowing time and subsequent interaction on nutrient uptake and yield production in rainfed soybean in red sandy loam soils. There were four dates of sowing viz., June II fortnight ( $\left.\mathrm{D}_{1}\right)$, July I fortnight $\left(\mathrm{D}_{2}\right)$, July II fortnight $\left(\mathrm{D}_{3}\right)$, August I fortnight $\left(\mathrm{D}_{4}\right)$ and three varieties of soybean viz.., DSb-21, JS-335 and JS 93-05. The results shown that among the different dates of sowing at $\left(D_{1}\right)$ June II fortnight recorded significant uptake compared to other sowing dates. Among the different varieties DSb-21 recorded the highest nutrient uptake followed by JS-335. The yield obtained among the different date of sowing has found to be better with $\mathrm{D}_{1}$-June II fortnight and it would give $7.5,26.94,39.4 \%$ more yield in soybean as compared to later sowing dates $\left(\mathrm{D}_{2}, \mathrm{D}_{3}\right.$ and $\mathrm{D}_{4}$ respectively). This study concluded that delay in sowing will reduce the nutrient uptake, dry matter production and yield irrespective of the varieties. Among the varieties highest yield was recorded by the variety DSb-21 irrespective of the sowing date. and hence under delayed sowing conditions the variety DSb-21 is preferred over other varieties.

Keywords: soybean varieties and nutrient uptake

\section{Introduction}

The performance of the crop depends mainly on the performance of the cultivar and the environmental area in which it grows. As far as a variety is concerned, its optimal sowing period plays a crucial role in the maximum exploitation of genetic potential as it offers the best possible growing conditions, such as sun, temperature, rainfall, humidity. The key causes of yield component variability have been reported to be genotypic, genotypic environmental interactions, and climatic variability in terms of temperature regime and availability of moisture.

One of the important agronomic factors affecting soybean production is the date of sowing. The environmental factors determining the optimum sowing date are the pattern of availability of moisture during plant growth, temperature and photoperiod. In a given area, the optimum sowing date depends mainly on the timing of the rainfall.

Proper agronomic management practices should also be established in order to help the crop to adapt the changing environmental condition. The nutrient uptake and yield of varieties in evolving weather conditions helps to pick the most promising varieties in terms of yield and productivity in the use of nutrients. With this view, field experiment was performed to define the most suitable variety, optimal sowing time and subsequent interactions on nutrient uptake in soybeans in a variety of environments.

\section{Materials and Methods}

Field experiment was carried out at Zonal Agricultural and Horticultural Research Station, Chikkamagalore, Karnataka (It is situated between 750 51' E longitude and $130420 \mathrm{~N}$ latitude with $667.51 \mathrm{~m}$ above MSL. in Southern transition zone (VII) of Karnataka) to study the performance of date of sowing on yield and nutrient uptake of three varieties of soybean in red sandy loam soil during the kharif 2109-20. The initial analysis of the the experimental soil contained 0.506 per cent organic carbon, $312.23 \mathrm{~kg} \mathrm{ha}^{-1}$ available nitrogen, $56.80 \mathrm{~kg} \mathrm{ha}{ }^{-1}$ available phosphorus and $232.78 \mathrm{~kg} \mathrm{ha}^{-1}$ available potassium with soil $\mathrm{pH} 5.56$. 
soil moisture content was measured initially gravimetric method during 2019 kharif season was 22 per cent. Experimental plot was laid out in factorial RCBD with three replications and plot was prepared by 2-3 times ploughing followed by leveling. The treatments were consisted of three varieties of soybean (DSb-21, JS-335 and JS 93-05) and Four date of sowing, (June II fortnight, July I fortnight, July II fortnight and August I fortnight). The sowing was done manually with seed rate of $80 \mathrm{~kg} \mathrm{ha}^{-1}$ at a row to row distance of $30 \mathrm{~cm}$ plant to plant $10 \mathrm{~cm}$.

A fertilizer dose of nitrogen @ $30 \mathrm{~kg} \mathrm{ha}^{-1}, \mathrm{P}_{2} \mathrm{O}_{5} @ 60 \mathrm{~kg} \mathrm{ha}^{-1}$ and $\mathrm{K}_{2} \mathrm{O} @ 30 \mathrm{~kg} \mathrm{ha}^{-1}$ was applied during sowing in the form of Urea, Single Super phosphate and Muriate of Potash respectively. Thinning was performed 15 days after germination to keep the plant to plant distance at $10 \mathrm{~cm}$ and optimal plant population. Hoeing was performed three times to keep the weed crop free. No irrigation was provided as the crop was grown as a rainfed crop. Various varieties were harvested on various dates depending on their maturity.

From each net plot five plants were selected at randomly for taking observations. For documenting the dry matter output plant samples from the field were dried in shade and then dried in the hot air furnace at $70{ }^{\circ} \mathrm{C}$. Dry weights were reported and mean values were calculated and expressed as $\mathrm{g}$ plant $^{-1}$. Morphological characteristics of varieties that can change due to evolving climatic factors such as seed yield, seed weight, seed index, etc. have been studied. Seed yield was reported by taking the total yield $\mathrm{ha}^{-1}$, the seed index by weighing 100 seeds from each treatment. For the study of plant nutrients, the oven dried samples were preserved in a layer of butter paper. The total nitrogen content of the plant sample was analysed using the adjusted micro-kjeldahl method used by Jackson. The total phosphorus content of the plant samples was measured using the vanadomolybdophosphoric yellow colour method and read in a spectrophotometer. The total potassium content of the plant samples was measured using a flame photometer as suggested by Jackson. Nutrient uptake was determined by multiplying the dry weight of the plant / seed by the nutrient concentration in the respective plant portion. The soil moisture content during the sowing, reproductive and harvesting phases was determined gravimetrically.

\section{Results and Discussion}

\section{Effect of Sowing Date on Nutrient Uptake}

The data clearly revealed that the sowing date significantly influenced the total nitrogen uptake in different growth stages of crop. Sowing at June II Fortnight resulted in a significantly high nitrogen uptake compared to the July II fortnight and August I fortnight sowing.

The delay in sowing might result in the plants to face a low light, photoperiod and high temperature in the later growing periods and hence affected the plant growth and biomass production, led to low nitrogen uptake. Also, it was noticed that among the varieties the nitrogen uptake was high in June II fortnight, compared to August I fortnight. The decrease in uptake of nitrogen during a delayed sowing may be due to the absence of rainfall during the crop growing period. The low growth and development might be due to less soil moisture and initial high temperature. This might be resulted in the low nitrogen fixation and hence the uptake also. These results are in conformity with the findings of Yadhalli and Palled (2012) ${ }^{[9]}$ and Jadhav et al. (2015) ${ }^{[4]}$.

The data clearly revealed that the sowing date significantly influenced the total phosphorus uptake in different growth stages of crop. The first date of sowing resulted in a significantly high phosphorus uptake compared to the third and fourth date of sowing. There was a drastic reduction of 36.21 per cent in the Phosphorus uptake in the third (July II fortnight) and 60.11 per cent at fourth (August I fortnight) sowing, respectively as compared to the first sowing date in during experiment.

Generally, soybean tend not to respond to phosphorus fertilizer even in soils with low available phosphorus status compared to other legumes and cereals, suggests that the crop is exceptionally efficient at taking up phosphorus from the soil. The more distributed rainfall during the early sowing might supply more soil moisture during the early crop development and nutrient uptake. This may be the reason for higher uptake of phosphorus in early sowing dates. If sufficient soil moisture is present, the availability of phosphorus may be enhanced due to the strong association of VAM (Vesicular Arbuscular Mycorhizal fungi) and roots and root acid exudates, which allow the plant to absorb more phosphorus from acidic soils.

The data clearly revealed that sowing date significantly influenced the total potassium uptake in different growth stages of soybean crop. The first date of sowing resulted in a significantly high potassium uptake compared to third (42.28 $\left.\mathrm{kg} \mathrm{ha}^{-1}\right)$ and fourth $\left(37.70 \mathrm{~kg} \mathrm{ha}^{-1}\right)$ date of sowing. There was a drastic reduction of 9.58 per cent in the potassium uptake in third (July II fortnight) and 39.95 per cent fourth (August I fortnight) sowing at harvest, compared to the first sowing date.

The highest potassium uptake was recorded with first date of sowing but it was and it was found to be on par with second sowing. The high potassium uptake might be attributed to the better weather and environmental conditions existing during the crop growth period. Wang et al. (2013) ${ }^{[8]}$. It claimed that there was a positive relationship between the uptake of $\mathrm{K}$ and the acquisition of water in the plant. As a result, the decrease in soil moisture affects the uptake of $\mathrm{K}$ and the overall production of biomass. This may be the reason for low uptake of $\mathrm{K}$ in delayed sowing, when there was low rainfall during the crop growing period.

\section{Interaction effect of sowing date and varieties on nutrient uptake}

Plant nitrogen uptake by varieties was differed significantly due to the different date of sowing. The highest nitrogen uptake by the variety DSb-21 was $130.15 \mathrm{~kg} \mathrm{ha}^{-1}$. But it was on par with the variety $\left(\mathrm{V}_{2}\right)$ JS-335 with nitrogen uptake of $125.59 \mathrm{~kg} \mathrm{ha}^{-1}$ harvest. At the same time lowest nitrogen uptake recorded by the variety $\left(\mathrm{V}_{3}\right) \mathrm{JS} 93-05$ was $116.57 \mathrm{~kg}$ $\mathrm{ha}^{-1}$ harvest. Due to short of rain there was a drastic reduction of moisture during the crop growth and development stage and high temperature affects the biological nitrogen fixation as well as nitrogen uptake. These findings are agreed with that of Dinh et al. (2014) ${ }^{[3]}$ and Neenu et al. (2017) ${ }^{[7]}$. 
Table 1: Effect of sowing date and varieties on total Nitrogen, phosphorus and potassium uptake $\left(\mathrm{kg} \mathrm{ha}^{-1}\right)$

\begin{tabular}{|c|c|c|c|}
\hline Treatments & Nitrogen $\left(\mathrm{kg} \mathrm{ha}^{-1}\right)$ & Phosphorus $\left(\mathrm{kg} \mathrm{ha}^{-1}\right)$ & Potassium $\left(\mathrm{kg} \mathrm{ha}^{-1}\right)$ \\
\hline \multicolumn{4}{|c|}{ Dates of sowing (D) } \\
\hline June II fortnight ( $\left.\mathrm{D}_{1}\right)$ & 145.95 & 22.03 & 57.22 \\
\hline July I fortnight $\left(\mathrm{D}_{2}\right)$ & 138.09 & 20.91 & 53.75 \\
\hline July II fortnight $\left(\mathrm{D}_{3}\right)$ & 115.98 & 14.59 & 42.28 \\
\hline August I fortnight $\left(\mathrm{D}_{4}\right)$ & 96.39 & 11.27 & 37.70 \\
\hline S. Em \pm & 3.686 & 0.642 & 1.271 \\
\hline $\mathrm{CD}$ at $5 \%$ & 10.811 & 1.884 & 3.727 \\
\hline \multicolumn{4}{|c|}{ Varieties (V) } \\
\hline $\mathrm{DSb}-21\left(\mathrm{~V}_{1}\right)$ & 130.15 & 18.29 & 49.90 \\
\hline $\mathrm{JS}-335\left(\mathrm{~V}_{2}\right)$ & 125.59 & 17.47 & 48.81 \\
\hline JS-93-05 $\left(\mathrm{V}_{3}\right)$ & 116.57 & 15.84 & 44.50 \\
\hline S.Em \pm & 3.192 & 0.556 & 1.100 \\
\hline $\mathrm{CD}$ at $5 \%$ & 9.362 & 1.632 & 3.227 \\
\hline \multicolumn{4}{|c|}{ Interaction $(\mathrm{D} \times \mathrm{V})$} \\
\hline S.Em \pm & 6.384 & 1.113 & 2.201 \\
\hline CD at $5 \%$ & NS & NS & NS \\
\hline
\end{tabular}

Plant phosphorus uptake by varieties was differed significantly due to the different date of sowing. The highest phosphorus uptake by the variety DSb-21 $18.29 \mathrm{~kg} \mathrm{ha}^{-1}$ at harvest respectively. But it was on par with the variety $\mathrm{V}_{2}$ (JS335 ) with a phosphorus uptake of $17.47 \mathrm{~kg} \mathrm{ha}^{-1}$. At the same time lowest phosphorus uptake recorded by the variety $\mathrm{V}_{3}$ (JS 93-05) was $15.84 \mathrm{~kg} \mathrm{ha}^{-1}$ ) harvest.

The difference in the uptake of phosphorus by varieties at different sowing dates attributed to the environmental conditions prevailing in the region. Efficient varieties can continuously consume nutrients even under unfavourable environmental conditions and perform better than inefficient varieties. Here, it was found that DSb-21 reported the highest phosphorus uptake in the different sowing dates, regardless of the weather variables, and demonstrated that it has ability to use the phosphate effectively. Genetic variability in phosphorus use efficiency was reported by Acrockinanathan (1983) and Marcante et al. (2016) ${ }^{[5]}$.

Potassium uptake by plant varieties was differed significantly due to the different date of sowing. The highest potassium uptake by the variety DSb-21 of soybean crop $49.38 \mathrm{~kg} \mathrm{ha}^{-1}$. But it was on par with the variety $\mathrm{V}_{2}$ (JS-335) with a potassium uptake of $49.33 \mathrm{~kg} \mathrm{ha}^{-1}$. At the same time lowest potassium uptake recorded by the variety $\mathrm{V}_{3}$ (JS 93-05) 44.50 $\mathrm{kg} \mathrm{ha}^{-1}$. Higher temperature and low soil moisture during the growing season may lead to a reduction in nutrient uptake. Plant potassium uptake is reported to be more sensitive than the uptake of other nutrients with changes in temperature, moisture content, aeration and compaction. These results were confirm with the findings of Neelaveni (2000) ${ }^{[6]}$ and Bilal Ahmadlone et al. (2009) ${ }^{[2]}$

\section{Interaction Effect of soybean varieties and date of sowing on nutrient uptake}

Among the interactions effects there was no significant difference was noticed between the dates of sowing and varieties with respect to nitrogen, phosphorus and potassium uptake.

\section{Conclusion}

The optimum sowing time for soybean depends on the relationship between the climate and the available germplasm of the variety. It can be a balance between optimising yield capacity and minimising disease levels to select an ideal sowing date. However, due to uneven weather conditions, such as lack of rainfall or excess rainfall, changes in temperature patterns, etc. and rainfed farming, sowing at an optimal time is often not feasible in the red sandy loam soils of the Southern Transitional Zone of Karnataka, India. It is reported from the present investigation that late sowing will reduce the uptake of nutrients.

\section{References}

1. Acrokianathan T. Performance of new chickpea (cicer arietinum) genotypes as influenced by dates of sowing and row spacing. Ph.D. dissertation, IARI, New Delhi 1983.

2. Bilal Ahmadlone, Badrul Hasan S, Ansar BA. Effect of seed rate, row spacing and fertility levels on growth and nutrient uptake of soybean (Glycine max. (L.) Merril) under temperate conditions. J Agric Biol Sci 2009;4(3):85-88.

3. Dinh HT, Wanwipa K, Sanun J, Nimitra V, Patanothal A. nutrient uptake of peanut genotypes with different levels of drought tolerance under midseason drought, Turk J Agric For 2014;38:495-505.

4. Jadhav A, Kumar A, Singh AK, Singh I, Das TK. Response of soybean (Glycine max L.) to staggered sowing. Indian J Agron 2015;60(3):476-479.

5. Marcante NC, Muroaka TB, Isabeli P, Camacho MA. Phosphorus uptake and use efficiency of different cotton cultivars in savannah soil (Acrisol). Acta Sci Agron 2016;38(9):239-247.

6. Neelaveni, Reddy DS, Sharma KL. Effect of different plant population densities of groundnut on NPK nutrient uptake and yield. Indian J of Dry land Agri. Res. and Develop 2000;15(1):19-21.

7. Neenu S, Ramesh K, Ramana S, Somasundaram J. Effect of cultivars and sowing dates on nutrient uptake and yield of chickpea under Aberrant Climatic Conditions in Black Soils of Central India. Adv in Res 2017;12(4):1-11.

8. Wang M, Zheng Q, Shen, Guo S. The critical role of potassium in plant stress response. Int $\mathrm{J}$ Mol Sci 2013;14(9):370-7390.

9. Yadahalli GS, Palled YB. Response of black gram genotypes to Dates of Sowing and Phosphorus Levels in Northern Transitional Tract of Karnataka. Karnataka J Agri Sci 2012;17(2):215-219. 